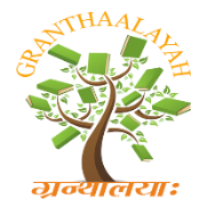

$$
\begin{gathered}
\text { INTERNATIONAL JOURNAL OF RESEARCH - } \\
\text { GRANTHAALAYAH } \\
\text { A knowledge Repository }
\end{gathered}
$$

Management

\title{
FACTORS AFFECTING ON THE PUBLIC ADMINISTRATORS' MANAGER CHOICE
}

\author{
Akın Erdemir ${ }^{1}$, Ramazan Erdem ${ }^{2}$ \\ ${ }^{* 1}$ Research and Application Hospital, Süleyman Demirel University, Turkey \\ ${ }^{2}$ Faculty of Economics and Administrative Sciences, Süleyman Demirel University, Turkey
}

\begin{abstract}
Motivation/Background: The aim of this research to evaluate that Public Perception on the Factors that Affecting Turkish Public Administrators' Manager Choice in Turkey.

Method: Quantitative research method was used in the research and the data obtained from the survey method were analyzed with SPSS (SPSS 16.0 for Windows, SPSS Inc. Chicago, IL, USA). Results: According to public perception, Turkish public administrators act in a favorable manner in the selection of managers.

Conclusions: According to the result of the research, participants think that the administrators in Turkish public sector mostly pay attention to the criteria for manager choice: relationship and citizenship factors, external influences and political factors and ethnicity and sect factors but they do not take representation and capability factors and merit criteria into account.
\end{abstract}

Keywords: Meritocracy; Perfectio; Manager Choice; Promoted on The Job.

Cite This Article: Akın Erdemir, and Ramazan Erdem. (2019). "FACTORS AFFECTING ON THE PUBLIC ADMINISTRATORS' MANAGER CHOICE.” International Journal of Research - Granthaalayah, 7(5), 173-185. https://doi.org/10.29121/granthaalayah.v7.i5.2019.837.

\section{Introduction}

Managers' merit (1) is very important as it contributes to achieving managerial function and organizational goals. Zaccaro and Banks (2) state that the desired managers' merit is the sum of the managers' experience, knowledge, skills and social positions as a whole. According to Shirazi and Mortazavi (3), merit should be a criterion in the evaluation process of the desired managers that the organizations seek to achieve their goals. Requesting qualifications related to merit (high

\footnotetext{
*This study is based on the $\mathrm{PhD}$ thesis titled "Public perception on the factors that affecting Turkish public administrators' management team choice: The case of Isparta" accepted by the Suleyman Demirel University, Graduate School of Social Sciences. Research and Application Hospital, Süleyman Demirel University, Turkey.
} 
motivation, etc.) from business managers is an important factor for organizational success (4-5). Mooney (6) also states that merit affects performance in an organization and thus provides to the organization to gain a significant competitive advantage. The current conditions necessitated adopting the principles of merit such as participation, transparency and accountability, fairness and consistency, and adopting management structures that offer confidence at the corporate level, for managers in the public sector as in the other two sectors (7). It is clear that the public manager selections that made in the direction of similarity or dissimilarity criteria (separatist tendency) do not meet the principles of meritocracy and would not lead to achieve managerial and organizational goals.

\section{Materials and Methods}

\subsection{Assumptions}

It was accepted that the participants' answers to the questionnaire used as data collection tools reflect the real situation.

\subsection{Limitations}

This study is limited to eighteen (18) and older individuals located in the Isparta city center between July and August 2017 and qualified to answer to the questionnaire designed for this research. Because of the results of the research reflect the characteristics of this particular participant group, these limitations should be considered while making a generalization based on the results of the study. It's necessary to study on larger and different samples is, when a generalization of the study needed in other states or countries.

\subsection{Population and Sample}

The participant group of this study is consisted of eighteen (18) and older individuals living in the center of Isparta. According to the data provided from Directorate of Civil Population of Isparta in 2016, the participant group of the research consists of 147,334 people ${ }^{3}$. Traditionally, it is not possible to state a certain amount about the size of the sample should be in a study. According to the current population size, a sample including about 384 individuals can be accepted as sufficient for this population to ensure a 5\% error tolerance and a 95\% confidence level (8). Almost 400 people were participated in the study and all of the questionnaires were used in the research. The convenience sampling method ${ }^{4}$ was used in the selection of the sample and the participants were determined accordingly.

\subsection{Data Collection Tool}

According to the literature survey, a suitable scale was not found for the purpose of the study. Therefore, the questions of the questionnaire were prepared by the author based on the conceptual framework determined from the literature survey. During preparing the questions of the

\footnotetext{
${ }^{3}$ http://www.ysk.gov.tr/ysk/docs/2011MilletvekiliSecimi/SecmenSandik2011.htm. (07.01.2017)
}

${ }^{4}$ A non-probability/non-random sampling technique. 
questionnaire; interviews were performed with relevant experts. A question pool including 350 questions was obtained from these interviews. These 350 questions were classified by the author based on the conceptual framework in the literature and thus, the number of questions decreased to almost 100 . These questions were also decreased to 63 , as a result of brainstorming session at a meeting with the participation of some colleagues studying in the similar topics. In order to obtain demographic information 9 questions were prepared and remaining 54 questions were designed in 5-Likert Scale format. Besides, a control question ${ }^{5}$ was inserted into these 54 questions. Consideration of the final questionnaire revealed that the expressions consisted of the following 7 dimensions; merit, external influences and politics, trust and loyalty, school and business environment, ethnic origin and sect, representation and talent, relatives and citizenship. AS a test application, a questionnaire including 63 questions were applied in the field to 100 people. Interviewers were performed to implement the questionnaire. Expressions of the participants were reviewed using an equally divided score ranges from 1 to 5 points; Totally disagree (1.0-1.79), Partially Disagree (1.80-2.59), Partially Agree (2.60-3.39), Mostly Agree (3.40-4.19), Totally Agree (4.20-5.0).

\subsection{Analysis Method}

Quantitative research method was used in the study and SPSS (SPSS 16.0 for Windows) software was utilized in the statistical analysis of the achieved data. Arithmetic mean, standard deviation, frequency and percentage calculations were carried out to determine descriptive statistics on the collected data. Statistical analysis of the study were carried out by using the averages obtained in these analysis. The normality test was applied to the data and the Skewness and Kurtosis values were obtained. Since the Skewness (-0.707) and Kurtosis (-1.209) values of the Trust and Loyalty Dimension was varied between -1.96 and +1.96 , this dimension was accepted as presented a normal (parametric) distribution (9-10). Accordingly, parametric tests were applied in comparison of demographic variables of this dimension. The significance test ( $\mathrm{t}$ test) of the difference between the two means was used to compare dual groups, and the variance analysis (ANOVA/F test) from the parametric tests was used to compare three or more groups. It was determined that the remaining 6 dimensions obtained in the research have not a normal distribution, since the Skewness and Kurtosis values were not fall between -1.96 and 1.96 and so did not meet the parametric assumptions (9-10). Thus, Whitney U test and Kruskal-Wallis variance analysis were applied to these dimensions. Confirmatory Factor Analysis (CFA) examines the degree of validation of a predetermined or designed structure, by using the total data (11). Because of the scale used in this study was not previously included in any study, DFA could not be performed for the results of the study.

\footnotetext{
5 To increase the reliability of the application, the 40th question was used as a control question. 


\subsection{Findings}

\subsubsection{Demographic Findings}

Table 1: Distribution of Participants According to Demographic Variables

\begin{tabular}{|c|c|c|}
\hline Variables & Frequency & Percent \\
\hline \multicolumn{3}{|l|}{ Age (Years) } \\
\hline $18-29$ & 152 & 40.3 \\
\hline $30-39$ & 102 & 27.1 \\
\hline $40+$ & 123 & 32.6 \\
\hline Total & 377 & 100 \\
\hline \multicolumn{3}{|l|}{ Sex } \\
\hline Male & 262 & 69.5 \\
\hline Female & 115 & 30.5 \\
\hline Total & 377 & 100 \\
\hline \multicolumn{3}{|l|}{ Marital Status } \\
\hline Married & 255 & 68.9 \\
\hline Single & 115 & 31.1 \\
\hline Total & 370 & 100 \\
\hline \multicolumn{3}{|c|}{ Monthly Income (TL) } \\
\hline$-1500 \mathrm{TL}$ & 51 & 14.5 \\
\hline $1501-2500 \mathrm{TL}$ & 89 & 25.3 \\
\hline $2501-3500 \mathrm{TL}$ & 147 & 41.8 \\
\hline $3501+\mathrm{TL}$ & 65 & 18.4 \\
\hline Total & 352 & 100 \\
\hline \multicolumn{3}{|l|}{ Education Level } \\
\hline -High School & 105 & 28.1 \\
\hline Associate degree & 111 & 29.7 \\
\hline College+ & 158 & 42.2 \\
\hline Total & 374 & 100 \\
\hline \multicolumn{3}{|c|}{ Employment Sector } \\
\hline Public & 213 & 58.7 \\
\hline Private & 117 & 32.2 \\
\hline Retired & 13 & 3.6 \\
\hline Un-employed & 20 & 5.5 \\
\hline Total & 363 & 100 \\
\hline \multicolumn{3}{|c|}{ Worked in any Public Management Team } \\
\hline Yes & 53 & 15.9 \\
\hline No & 280 & 84.1 \\
\hline Total & 333 & 100 \\
\hline Grand Total & 400 & $\mathbf{1 0 0 . 0}$ \\
\hline
\end{tabular}




\subsubsection{Arithmetic Mean and Standard Deviation Findings}

Table 2: Findings of the Factors Expressed by the Participants about the Tendency of Turkish Public Administrators' (TPA) Manager Choice

\begin{tabular}{|c|c|c|c|c|}
\hline No & EXPRESSIONS & $\bar{X}$ & SS & $\begin{array}{l}\text { Factor } \\
\text { Load }\end{array}$ \\
\hline 1 & $\begin{array}{l}\text { TPM prefers the relatives and acquaintances while selecting } \\
\text { managers. }\end{array}$ & 4.768 & 0.582 & 0.712 \\
\hline 2 & TPM prefers their fellow citizens while selecting managers. & 4.755 & 0.588 & 0.670 \\
\hline 3 & $\begin{array}{l}\text { TPM prefers people who are in their group of friends, while } \\
\text { selecting managers. }\end{array}$ & 4.705 & 0.632 & 0.570 \\
\hline 4 & $\begin{array}{l}\text { TPM prefers people who graduated from same school, while } \\
\text { selecting managers. }\end{array}$ & 4.505 & 0.855 & 0.595 \\
\hline 5 & $\begin{array}{l}\text { TPM prefers people who have same political view, while } \\
\text { selecting managers. }\end{array}$ & 4.848 & 0.458 & 0.796 \\
\hline 6 & $\begin{array}{l}\text { TPM prefers people who have the same profession, while } \\
\text { selecting managers. }\end{array}$ & 4.492 & 0.958 & 0.743 \\
\hline 7 & $\begin{array}{l}\text { TPM prefers people who are members of the same union, while } \\
\text { selecting managers. }\end{array}$ & 4.825 & 0.539 & 0.476 \\
\hline 8 & $\begin{array}{l}\text { TPM prefers people who are members of the same religious } \\
\text { group, while selecting managers. }\end{array}$ & 4.802 & 0.570 & 0.487 \\
\hline 9 & $\begin{array}{l}\text { The bureaucratic pressure arising from the upper tiers is } \\
\text { effective for TPM while selecting managers. }\end{array}$ & 4.803 & 0.499 & 0.760 \\
\hline 10 & $\begin{array}{l}\text { Ethnic origin (Turkish, Kurdish, Laz, Cherkes etc.) of the } \\
\text { candidate is effective for TPM while selecting managers. }\end{array}$ & 4.560 & 0.853 & 0.898 \\
\hline 11 & Financial gain is effective for TPM while selecting managers. & 4.677 & 0.781 & 0.514 \\
\hline 12 & $\begin{array}{l}\text { The pressures of the private sector companies through politics } \\
\text { are effective for TPM while selecting managers. }\end{array}$ & 4.683 & 0.684 & 0.424 \\
\hline 13 & $\begin{array}{l}\text { Social perception (communitarianism, communist, follower of } \\
\text { sharia, leftist/rightist etc.) about the executive candidates is } \\
\text { effective for TPM while selecting managers. }\end{array}$ & 4.800 & 0.548 & 0.791 \\
\hline 14 & $\begin{array}{l}\text { The perception (communitarianism, communist, follower of } \\
\text { sharia, leftist/rightist etc.) of senior bureaucrats and politicians } \\
\text { about the executive candidates is effective for TPM while } \\
\text { selecting managers. }\end{array}$ & 4.782 & 0.544 & 0.807 \\
\hline 15 & $\begin{array}{l}\text { The way in which the manager obtains his position (politics, } \\
\text { sect, communitarianism, union, merit, etc.), is effective for } \\
\text { TPM while selecting managers. }\end{array}$ & 4.759 & 0.542 & 0.798 \\
\hline 16 & TPM prefers sycophant people while selecting managers. & 4.675 & 0.700 & 0.538 \\
\hline 17 & $\begin{array}{l}\text { TPM prefers people from the leading families of the city while } \\
\text { selecting managers. }\end{array}$ & 4.231 & 1.124 & - \\
\hline 18 & $\begin{array}{l}\text { The Sect (Sunnism, Alawism etc.) of the candidate is effective } \\
\text { for TPM while selecting managers. }\end{array}$ & 4.375 & 1.038 & 0.893 \\
\hline
\end{tabular}




\begin{tabular}{|c|c|c|c|c|}
\hline 19 & $\begin{array}{l}\text { TPM prefers people who worked with them before while } \\
\text { selecting managers. }\end{array}$ & 4.499 & 0.906 & \\
\hline 20 & $\begin{array}{l}\text { The Intelligence of the candidate is effective for TPM while } \\
\text { selecting managers. }\end{array}$ & 1.729 & 1.076 & 0.530 \\
\hline 21 & $\begin{array}{l}\text { The loyalty of the candidate is effective for TPM while selecting } \\
\text { managers. }\end{array}$ & 3.887 & 1.494 & 0.951 \\
\hline 22 & $\begin{array}{l}\text { The faithfulness of the candidate is effective for TPM while } \\
\text { selecting managers. }\end{array}$ & 3.860 & 1.519 & 0.973 \\
\hline 23 & $\begin{array}{l}\text { The privacy and secrecy behavior of the candidate is effective } \\
\text { for TPM while selecting managers. }\end{array}$ & 3.842 & 1.557 & 0.958 \\
\hline 24 & $\begin{array}{l}\text { TPM prefers people who was taken part in the management } \\
\text { team of one of the previous managers, while selecting } \\
\text { managers. }\end{array}$ & 1.477 & 0.963 & 0.760 \\
\hline 25 & $\begin{array}{l}\text { Professional reference is effective for TPM while selecting } \\
\text { managers. }\end{array}$ & 4.180 & 1.295 & 0.854 \\
\hline 26 & $\begin{array}{l}\text { TPM considers providing a social equilibrium in a way that } \\
\text { constitutes the mosaic structure (where every section is fairly } \\
\text { represented) while selecting managers. }\end{array}$ & 1.447 & 0.922 & 0.713 \\
\hline 27 & $\begin{array}{l}\text { TPM considers the requests/demands of the lower levels within } \\
\text { the organization, while selecting managers. }\end{array}$ & 3.648 & 1.513 & - \\
\hline 28 & $\begin{array}{l}\text { TPM considers professional reference while selecting } \\
\text { managers. }\end{array}$ & 3.650 & 1.638 & - \\
\hline 29 & $\begin{array}{l}\text { TPM considers the requests of managers of the other } \\
\text { organizations, while selecting managers. }\end{array}$ & 4.640 & 0.814 & 0.422 \\
\hline 30 & $\begin{array}{l}\text { TPM prefers people who have a common motivation feature, } \\
\text { while selecting managers. }\end{array}$ & 1.990 & 1.319 & 0.546 \\
\hline 31 & $\begin{array}{l}\text { TPM considers the potential of the candidate for being a } \\
\text { competitor in the future while selecting managers. }\end{array}$ & 4.465 & 1.089 & - \\
\hline 32 & $\begin{array}{l}\text { TPM prefers people who do not give up their values while } \\
\text { selecting managers. }\end{array}$ & 1.432 & 0.864 & - \\
\hline 33 & $\begin{array}{l}\text { TPM prefers people who have a High Level Questioning } \\
\text { Ability, while selecting managers. }\end{array}$ & 1.502 & 0.788 & 0.768 \\
\hline 37 & TPM prefers well-educated people while selecting managers. & 1.646 & 0.955 & 0.763 \\
\hline 38 & $\begin{array}{l}\text { TPM prefers people who have the highest specialized } \\
\text { knowledge in the field to be studied, while selecting managers. }\end{array}$ & 1.621 & 0.863 & 0.907 \\
\hline 39 & $\begin{array}{l}\text { TPM prefers experienced people in the field to be studied, while } \\
\text { selecting managers. }\end{array}$ & 1.690 & 0.955 & 0.809 \\
\hline 40 & $\begin{array}{l}\text { TPM prefers while selecting managers this is a control question, } \\
\text { please mark } 1 .\end{array}$ & 1.00 & 0 & - \\
\hline 41 & $\begin{array}{l}\text { TPM prefers people who have teamwork skills, while selecting } \\
\text { managers. }\end{array}$ & 1.510 & 0.824 & 0.770 \\
\hline 42 & TPM prefers people who have vision, while selecting managers. & 1.596 & 0.975 & 0.742 \\
\hline
\end{tabular}


DOI: 10.5281/zenodo.3238376

\begin{tabular}{|l|l|c|c|c|}
\hline $\mathbf{4 3}$ & $\begin{array}{l}\text { TPM prefers people who have succeeded in the field before, } \\
\text { while selecting managers. }\end{array}$ & 1.623 & 0.918 & 0.803 \\
\hline $\mathbf{4 4}$ & $\begin{array}{l}\text { TPM prefers people who have high communication abilities, } \\
\text { while selecting managers. }\end{array}$ & 1.550 & 0.871 & 0.808 \\
\hline $\mathbf{4 5}$ & $\begin{array}{l}\text { TPM prefers people who display high adaptive skills, while } \\
\text { selecting managers. }\end{array}$ & 1.536 & 0.884 & 0.754 \\
\hline $\mathbf{4 6}$ & $\begin{array}{l}\text { TPM prefers people who have a better foreign language } \\
\text { knowledge, while selecting managers. }\end{array}$ & 1.672 & 1.097 & 0.700 \\
\hline $\mathbf{4 7}$ & $\begin{array}{l}\text { TPM prefers people who can use the technology in a better way, } \\
\text { while selecting managers. }\end{array}$ & 1.619 & 0.998 & 0.750 \\
\hline $\mathbf{4 8}$ & TPM prefers hardworking people while selecting managers. & 1.647 & 1.008 & 0.862 \\
\hline $\mathbf{4 9}$ & $\begin{array}{l}\text { TPM prefers people with high levels of personal morality while } \\
\text { selecting managers. }\end{array}$ & 1.660 & 0.993 & 0.739 \\
\hline $\mathbf{5 0}$ & $\begin{array}{l}\text { TPM prefers people with high levels of professional morality } \\
\text { while selecting managers. }\end{array}$ & 1.598 & 0.934 & 0.727 \\
\hline $\mathbf{5 1}$ & $\begin{array}{l}\text { TPM prefers people who display high levels of equity law, } \\
\text { while selecting managers. }\end{array}$ & 1.572 & 0.923 & 0.761 \\
\hline $\mathbf{5 2}$ & $\begin{array}{l}\text { TPM prefers people with sharing talent while selecting } \\
\text { managers. }\end{array}$ & 1.532 & 0.928 & 0.886 \\
\hline $\mathbf{5 3}$ & TPM prefers challenging people while selecting managers. & 1.542 & 0.914 & 0.884 \\
\hline $\mathbf{5 4}$ & $\begin{array}{l}\text { TPM prefers people who display high levels of problem solving } \\
\text { ability, while selecting managers. }\end{array}$ & 1.505 & 0.931 & 0.924 \\
\hline
\end{tabular}

Merit Dimension

External Influences and Politics Dimension

Trust and Loyalty Dimension

School and Business Environment Dimension

Ethnic Origin and Sect Dimension

Representation and Talent Dimension

Relatives and Citizenship Dimension

Excluded from Evaluation

According to the highly-rated factors expressed by the participants, the factors that considered as important for Turkish public administrators while selecting their management teams, are listed below respectively;

- Having same political view, 
- Being a member of the same union,

- The situation of bureaucratic pressure from the upper tiers,

- Being in the same religious group,

- Social perception (communitarianism, communist, follower of sharia, leftist/rightist etc.) about the executive candidates to be selected for the team,

- The perception (communitarianism, communist, follower of sharia, leftist/rightist etc.) of senior bureaucrats and politicians about the manager candidates to be selected for the team,

- to be one of close relatives and acquaintances,

- The way in which the administrator obtains his position (politics, sect, communitarianism, union, merit, etc.),

- Being a fellow citizen,

- Being one of the friends.

According to the low-rated factors expressed by the participants, the factors that considered as less important Turkish public administrators while selecting their management teams, are listed below respectively;

- Displaying a high level of Innovation,

- Displaying a high level of communication ability,

- Initiative,

- Displaying a high level of adaptive skill,

- Having sharing abilities,

- Having teamwork skills,

- Displaying a high level of problem solving ability,

- Having a high level of questioning ability,

- To have taken part in the management team of one of the previous managers,

- Making the selection of executives by considering the social equilibrium in a way that constitutes the mosaic structure (where every section is fairly represented).

\subsubsection{Factor Loads and Percentages of Explained Variance}

The Percentages Variance of the Dimensions obtained in the study were calculated as follows;

Merit Dimension $\quad$ : \% 17.8

External Influences and Politics Dimension $\quad: \% 12.7$

Trust and Loyalty Dimension $\quad: \% 5.4$

School and Business Environment Dimension $\quad: \% 6.9$

Ethnic Origin and Sect Dimension $\quad: \% 4.8$

Representation and Talent Dimension $\quad: \% 4.0$

Relatives and Citizenship Dimension $\quad: \% 3.9$

As a result of the examination; the expressions in the 17, 19,27 and 28th questions, which were found to be overlapped, were removed from the scale. On the other hand, the expressions in the 31st and 32th questions, which were found to be single factors because they consisted of only one question, were excluded from the scale. Finally, the control question in the 40th expression, which was used to increase the reliability of the study, was also excluded from the scale. In summary, 
seven expressions in the $17,19,27,28,31,32$ and 40th questions were excluded from the scale of the study for various reasons mentioned above. The number of valid expressions in the scale was determined as $47(21+12+4+3+2+3+2)$.

Table 3: Descriptive Statistical Data of the Factors

\begin{tabular}{|c|c|c|c|c|c|c|c|}
\hline DIMENSIONS & Merit & $\begin{array}{c}\text { External } \\
\text { Influences } \\
\text { and } \\
\text { Politics }\end{array}$ & $\begin{array}{c}\text { Trust } \\
\text { and } \\
\text { Loyalty }\end{array}$ & $\begin{array}{c}\text { School and } \\
\text { Business } \\
\text { Environment }\end{array}$ & $\begin{array}{c}\text { Ethnic } \\
\text { Origin } \\
\text { and Sect }\end{array}$ & $\begin{array}{c}\text { Representation } \\
\text { and Talent }\end{array}$ & $\begin{array}{c}\text { Relatives } \\
\text { and } \\
\text { Citizenship }\end{array}$ \\
\hline $\begin{array}{c}\text { Number of } \\
\text { Expressions }\end{array}$ & 21 & 12 & 4 & 3 & 2 & 3 & 2 \\
\hline$\overline{\mathbf{x}}$ & 1.608 & 4.749 & 3.830 & 4.390 & 4.467 & 1.550 & 4.761 \\
\hline SS & 0.743 & 0.425 & 1.408 & 0.852 & 0.848 & 0.736 & 0.559 \\
\hline $\boldsymbol{\alpha}$ & 0.969 & 0.900 & 0.932 & 0.727 & 0.748 & 0.598 & 0.906 \\
\hline Skewness & 2.166 & -4.298 & -0.707 & -1.861 & -2.343 & 2.043 & -3.862 \\
\hline Kurtosis & 5.47 & 26.681 & -1.209 & 3.541 & 5.848 & 4.649 & 19.576 \\
\hline
\end{tabular}

In accordance with the ranking results of the factor analysis, statistical analyzes was performed on the 47-item scale and its dimensions. As a result of the analysis, Cronbach Alpha reliability coefficients, arithmetic mean, standard deviation, Skewness and Kurtosis values were calculated for all dimensions of the scale. According to the obtained results; because of the Skewness (-0.707) and Kurtosis (-1.209) values of the Trust and Loyalty Dimension was in the range of -1.96 to +1.96 , this dimension was accepted as displaying a normal (parametric) distribution (9-10). Other dimensions did not display a normal distribution, because the Skewness and Kurtosis values of these dimensions were not in the range of -1.96 to $+1.96(9-10)$.

According to the Cronbach Alpha $(\alpha)$ coefficient, the confidence intervals of the dimensions in the study are as follows: Merit Dimension, Relatives and Citizenship Dimension, External Influences and Politics Dimension and Trust and Loyalty Dimensions were determined as display "high reliability" because of these dimensions fulfill the $0.80 \leq \alpha \square 1.00$ condition (12). The School and Business Environment and Ethnic Origin and Sect Dimensions were determined as display "moderate reliability" because of these dimensions fulfill the $0.60 \leq \alpha \square 0.80$ condition. And, the Representation and Talent Dimension was determined as display "low reliability" because of this dimension fulfill the $0.40 \leq \alpha \square 0.60$ condition.

\subsubsection{KMO and Barlett Test Findings}

Table 4: KMO and Barlett Test Results

\begin{tabular}{|l|l|c|}
\hline \multirow{4}{*}{ Bartlett's Test of Sphericity } & Kaiser-Meyer- Olkin Test for Sampling Adequacy & $\mathbf{0 . 9 3 3}$ \\
\cline { 2 - 3 } & Chi-Square Approximation & 17018.589 \\
\cline { 2 - 3 } & Degree of Freedom & 1378 \\
\cline { 2 - 3 } & Significance & $\mathbf{0}$ \\
\hline
\end{tabular}


According to the Table 4, the KMO value of the scale is 0.93 . Considering the table created by Sipahi et al. including KMO values and comments; it is determined that the suitability level of the variables used in this study to the factor analysis is excellent (13). Kalayc1 also states that the higher the KMO value, the better the dataset is for factor analysis (12). Bartlett's Test of Sphericity is used to examine the hypothesis that the variables of the main structure are unrelated or not. According to the " 0 " value indicated in the Table 7 , which fulfills the $\mathrm{p}<0.01$ condition, results of the Bartlett's Test of Sphericity used in the study are significant.

\section{Results and Discussions}

According to the results obtained from the dimensions of the research, the public perception about the factors that affecting Turkish public administrators' manager choice can be summarized as follows:

The public perception about the Merit Factor: According to the public perception, the Merit Factor is not a determinative factor for Turkish public administrators' manager choice.

The public perception about the External Influences and Politics Factor: According to the public perception, the External Influences and Politics Factor is a determinative factor in Turkish public administrators' manager choice.

The public perception about the Trust and Loyalty Factor: According to the public perception, the Trust and Loyalty Factor is a determinative factor in Turkish public administrators' manager choice.

The public perception about the School and Business Environment Factor: According to the public perception, the School and Business Environment Factor is a determinative factor in Turkish public administrators' manager choice.

The public perception about the Ethnic Origin and Sect Factor: According to the public perception, the Ethnic Origin and Sect Factor is a determinative factor in Turkish public administrators' manager choice.

The public perception about the Representation and Talent Factor: According to the public perception, the Representation and Talent Factor is definitely not a determinative factor in Turkish public administrators' manager choice.

The public perception about the Relatives and Citizenship Factor: According to the public perception, the Relatives and Citizenship Factor is a determinative factor in Turkish public administrators' manager choice.

According to the findings above, the results of the research can be summarized as follows: participants stated that Turkish public administrators mostly pay attention to factors such as relatives and citizenship, external influences and politics, ethnic origin and sect, school and business environment, and trust and loyalty while selecting managers, but they ignore the criteria of merit, representation and ability, and thus acting with favoritism. Likewise, this perception is consistent with the definition of favoritism of Bozkurt et al. (14). According to this definition, favoritism (14) is that people, who hold public opportunities, behave in a manner that provides both professional or pecuniary advantages to people close to them, both in terms of kinship and political views, or due to other particular reasons.

It is understood that, in the selection of public managers in Turkey clear and certain legal regulations in accordance with the principle of meritocracy are needed. Ak and Sezer (15) also 
stated that there are no clear criteria in the appointment of public managers and that the principles of promotion in the public should have certain criteria. It is considered that the legal gaps and uncertainties that political authority did not correct in order to keep room for maneuver are the main determinants for the merit of public managers. The public administrators, who get promotion with favoritism, are not able to remain independent in terms of his responsibilities in order to keep his current position and continue to promote.

It is considered that the Council of Ethics for Public Service should increase the effectiveness of the selection method, procedures and inspection of the public managers. Similar recommendations regarding this issue (15) are also included in different research results.

It is considered that one of the factors for being the public perception about merit is so negative in Turkey is due to lack of education of the selected person as manager about the organization and management. Depending on this situation, people who specialize in management sciences could not perform their specialties because they cannot find the opportunity. Ünal and Aydoğan (16) also stated that $82 \%$ of participating managers in the health sector admitted that they did not receive a health management education. According to Rauch and Evans (17), the application of meritocracy principles on civil servants is an inseparable element of professional bureaucracy.

It should not be allowed to attempt to give managerial skills to the people, who is not qualified, by public opportunities. Public damages caused by managers, who do not have any managerial experience, basic management competencies such as financial management, strategic management, etc., should be considered. Günay (18) also states that competent people who are knowing, experienced and capable for the requirements of the task should be brought into management duties as a requirement of the qualification principle, and also to use qualified human resources efficiently. It is a widespread finding that some public employees do not have the capacity to perform their duties effectively in the developing countries (19-20).

The general result of the study indicated that the previous legal arrangements made in good faith with the aim of removing the incompetent and unacquainted managers from their positions in the public sector and bringing the qualified and capable persons to their places, unfortunately, have not reached its goal according to the public perception.

It is thought that the last legal arrangements that started in good faith should be continued with the same intention and stability, and the uncertainties and gaps should be completed without losing any time and without leading to chronic (glass ceiling, learned helplessness etc.) organizational and managerial diseases in the public sector. Otherwise (21), confidence, job satisfaction, organizational commitment and individual performance levels in the organization may be adversely affected.

\section{Conclusions and Recommendations}

According to the result of the research, participants think that the administrators in Turkish public sector mostly pay attention to the criteria for manager choice: relationship and citizenship factors, external influences and political factors and ethnicity and sect factors but they do not take representation and capability factors and merit criteria into account. 
Based on the results of the study the following suggestions can be made;

- Legal uncertainties and gaps that give an opportunity to surpassing meritocracy principles in the selection of Turkish public manager, should be filled.

- It is considered that a public authority that provided with enhanced powers should treat the problem.

- In the selection of Turkish public manager, an education at least at the graduate level must be required regarding the area to be studied.

- In the selection of Turkish public manager, an experience must be required in accordance with the risk and responsibility of the task to be performed.

- The managerial activities of the selected public managers should be monitored, and the reward and penalty responsibilities should be applied based on the actual performance criteria.

- It is suggested that policies aimed at increasing the number of job opportunities and qualified human source are an important factor in the solution of the problem.

- It is thought that both quantitative and qualitative studies performed on the Turkey's local examples and original dynamics about concepts that have same relationship hinterland, such as discrimination and favoritism, will contribute to the solution of the problems and the literature.

\section{References}

[1] Çetinkaya, M., and Özutku, H., Yönetsel Performansa Yetkinlik Temelli Yaklaşım: Türk Otomotiv Sektöründe Bir Araştırma. İstanbul Üniversitesi İşletme Fakültesi Dergisi. Vol. 41, No. 1, 2012, 142-161.

[2] Zaccaro, S. J., and Banks, D., Leader Visioning and Adaptability: Bridging the Gap Between Research and Practice on Developing The Ability to Manage Change. Human Resource Management Journal. Vol. 43, No. 4, 2004, 367-380.

[3] Shirazi, A. and Mortazavi, K., Effective Management Performance A Competency Based Perspective. İnternational Review of Business Research Papers. Vol. 5, No. 1, 2009, 4-10.

[4] Kubica, A. J., Transcitioning Middle Managers. Healthcare Executive, Vol. 23, No. 1, 2008,58-60.

[5] Broscio, M., and Scherer, J., Bulding Job Security: Strategies for Becoming A Highly Valued Contributor. Journal of Healthcare Management, Vol. 48, No. 4, 2003, 147-151.

[6] Mooney, A., Core Competence, Distinctive Competence and Competitive Advantage: What Is the Difference? Journal of Education for Business, Vol. 83, No. 2, 2007, 110-115.

[7] Argüden, Y., Yönetim Kurulu Sırları. İstanbu: Rota Yayın Yapım Tanıtım Tic. Ltd. Şti., 2007, 10.

[8] Kan, İ., Biyoistatistik, Bursa: Uludağ Üniversitesi Basımevi, 1998.

[9] Can, A., SPSS ile Bilimsel Araştırma Sürecinde Nicel Veri Analizi (in Turkish). Ankara: Pegem Akademi, 2014.

[10] Akgül, A. and Çevik, O., İstatistiksel Analiz Teknikleri (in Turkish). Ankara: Emek Ofset, 2005.

[11] Seçer, İ., SPSS ve LİSREL ile Pratik Veri Analizi (in Turkish). Ankara: Anı Yayıncılık, 2013.

[12] Kalaycı, Ş., SPSS Uygulamalı Çok Değişkenli İstatistik Teknikleri (in Turkish). Ankara: Asil Yayın Dağıtım, 2008.

[13] Sipahi, B., Yurtkoru, S., and Çinko, M., Sosyal Bilimlerde SPSS'le Veri Analizi (in Turkish). İstanbul: Beta Yayınları, 2006.

[14] Bozkurt, Ö., Ergun, T., and Sezen, S., Kamu Yönetimi Sözlüğü. Ankara:TODAİE Yayını, 2011, 145. 
[15] Ak, M. and Sezer, Ö., Kamu Personel Sisteminde Çalışanların Görevde Yükselmesinde Kayırmac1lık Sorunu. Süleyman Demirel Üniversitesi İktisadi ve İdari Bilimler Fakültesi Dergisi, Vol. 23, Special Issue in memory of Geybulla Ramazanoğlu, 2018, 739-757.

[16] Ünal, A. K., \& Aydoğan, E., Kamu Hastanelerindeki Sağlık Yöneticilerinin Yetkinlikleri. İşletme Araştırmaları Dergisi, Vol. 10, No. 3, 2018, 520-545.

[17] Rauch, J. and Evans, P. Bureaucratic Structure and Bureaucratic Performance in Less Developed Countries. Journal of Public Economics, Vol. 75, No. 1, 2000, 49-71.

[18] Günay, Ö. F., Üst Düzey Kamu Yöneticilerinin Yetiştirilmesi, Doktora Tezi. Ankara: Sosyal Bilimler Enstitüsü, Ankara Üniversitesi, 2004, 79.

[19] Huber, J. D., \& Mccarty, N., Bureaucratic Capacity,Delegation, and Political Reform. The American Political Science Review, Vol. 98, No. 3, 2004, 481-494.

[20] Haque, M., Incongruity Between Bureaucracy and Society in Developing Nations: A Critique. Peace \& Change, Vol. 22, No. 4, 1997, 432-462.

[21] Büte, M., Nepotizmin İş Stresi, İş Tatmini, Olumsuz Söz Söyleme Ve İşten Ayrılma Niyeti Üzerine Etkileri: Aile İşletmeleri Üzerinde Bir Araştırma, Ç.Ü. Sosyal Bilimler Enstitüsü Dergisi, Vol. 20, No. 1, 2011, 177-194.

*Corresponding author.

E-mail address: akinerdemir@ sdu.edu.tr 